Article

\title{
C3 and C4 Grass Species: Who Can Reduce Soil Nitrous Oxide Emissions in a Continental Arid Region?
}

\author{
Jiao Ning ${ }^{1}$, Xiong Z. $\mathrm{He}^{2} \mathbb{D}$ and Fujiang Hou ${ }^{1, *}$ \\ 1 State Key Laboratory of Grassland Agro-ecosystems, Key Laboratory of Grassland Livestock Industry \\ Innovation Ministry of Agriculture, College of Pastoral Agriculture Science and Technology, \\ Lanzhou University, Lanzhou 730020, China; ningj10@lzu.edu.cn \\ 2 School of Agriculture and Environment, College of Science, Massey University, Private Bag 11222, \\ Palmerston North 4442, New Zealand; x.z.he@massey.ac.nz \\ * Correspondence: cyhoufj@lzu.edu.cn
}

Received: 6 July 2020; Accepted: 5 September 2020; Published: 8 September 2020

\begin{abstract}
In order to relieve grazing pressure, drought-tolerant grass species are widely cultivated in arid regions. However, soil $\mathrm{N}$ emission is largely neglected while pursuing forage yield. We carried out a randomized block study to investigate whether and how the C3 and C4 grass species differ in soil $\mathrm{N}$ emission in a typical salinized field with temperate continental arid climate in the northwest inland regions, China. We quantified soil $\mathrm{N}_{2} \mathrm{O}$ flux from two $\mathrm{C} 3$ (barley and rye) and two $\mathrm{C} 4$ grass species [corngrass and sorghum hybrid sudangrass (SHS)] in fields during the growing season (from May to September) by using the static box method, and then determined the relationships between soil $\mathrm{N}_{2} \mathrm{O}$ fluxes and forage yield and soil properties. Results show that soil available nitrogen, soil temperature, $\mathrm{pH}$, soil organic carbon, and total nitrogen were correlated, but soil water was anti-correlated with soil $\mathrm{N}_{2} \mathrm{O}$ fluxes. In addition, $\mathrm{N}_{2} \mathrm{O}$ flux increased significantly faster with soil temperature in $\mathrm{C} 4$ than in $\mathrm{C} 3$ grass fields. Although the lower total $\mathrm{N}_{2} \mathrm{O}$ emission fluxes were detected for $\mathrm{C} 3$ species, the lower yield-scaled $\mathrm{N}_{2} \mathrm{O}$ was detected for $\mathrm{C} 4$ species. Our study provided insights into the determination of grass species and the understanding of mechanisms regulating $\mathrm{N}_{2} \mathrm{O}$ fluxes in $\mathrm{C} 3$ and $\mathrm{C} 4$ species in the continental arid regions.
\end{abstract}

Keywords: greenhouse gas; denitrification; soil organic carbon; hay yield; crude protein yield; pasture

\section{Introduction}

Crops and livestock are the core components of an agricultural system, and their interaction drives the continuous evolution of agricultural systems. Forage crops sustain more than $70 \%$ of sheep and goat, as well as 50\% of meat products in the world [1]. In China, more than $60 \%$ of cultivated land is located in arid and semi-arid areas [2], where stall-feeding rather than grazing is the main model of livestock production due to the serious seasonal drought [3]. Therefore, in recent years crop forages have been widely planted to meet the increasing demand for meat products and release grazing pressure in these areas. Gramineae grass is one kind of the most important forage crops, and some annual grass species are very productive even under arid conditions [4-6]. Compared to C3 species, C4 species are more suitable for growing in an arid region due to shrinking pore diameter and then reducing transpiration and water loss under drought. Land-use in which intensified C3 species are strategically diversified with C4 species may lead to benefits for soil microbiological diversity [7], soil water content and $\mathrm{N}$ use efficiencies [8], soil carbon sequestration [9], and other ecosystem services including saline-alkali land improvement [10]. Despite considerable recent research try to better understand these factors, the differences between both species of grass system in term of $\mathrm{N}_{2} \mathrm{O}$ emission 
remain poorly understood, even though grassland represents a great anthropogenic source of these emissions [11,12]. As a potent greenhouse gras (GHG), $\mathrm{N}_{2} \mathrm{O}$ has a global warming potential 298 times of carbon dioxide and is the most important ozone-depleting emission [13,14].

Soil $\mathrm{N}_{2} \mathrm{O}$ fluxes are driven by nitrification (oxidation of $\mathrm{NH}_{4} \mathrm{C}$ to $\mathrm{NO}_{3}{ }^{-}$via $\mathrm{NO}_{2}{ }^{-}$) under aerobic conditions and denitrification (reduction of $\mathrm{NO}_{3}{ }^{-}$to $\mathrm{N}_{2} \mathrm{O}$ and $\mathrm{N}_{2}$ ) under anaerobic conditions, which are mainly related to the balance between soil $\mathrm{NO}_{3}{ }^{-}-\mathrm{N}$ and $\mathrm{NH}_{4}{ }^{+}-\mathrm{N}$ concentrations [15]. These two processes affecting soil $\mathrm{N}_{2} \mathrm{O}$ emission are mediated by soil physic-chemical properties, such as soil temperature, soil water content, soil organic carbon, total nitrogen, and $\mathrm{pH}$ [16-18]. Therefore, the difference of $\mathrm{N}_{2} \mathrm{O}$ emission between $\mathrm{C} 3$ and $\mathrm{C} 4$ grass soils is inevitable because they regulate the biotic and abiotic factors driving $\mathrm{N}_{2} \mathrm{O}$ emissions in diverging ways [7-10]. In addition, the forage productivity may also differ between both types, affecting the use efficiency of plants for soil water and nutrient resources [19]. At present, although the plant types have been found to be one of the key factors governing $\mathrm{N}_{2} \mathrm{O}$ emission [20], whether the changes of soil properties caused by $\mathrm{C} 3$ and $\mathrm{C} 4$ species will significantly influence $\mathrm{N}_{2} \mathrm{O}$ emission flux is still unknown.

Previous studies regarding GHG emissions in healthy $\mathrm{C} 3$ and $\mathrm{C} 4$ grass lands have focused on $\mathrm{CO}_{2}$ [21-23], while few pieces of research have explored the mechanism of $\mathrm{N}_{2} \mathrm{O}$ emission. Salinization is an enormous challenge to environmental resources, and the area of salinization land accounts for more than $50 \%$ of the arable land around the world [24]. Soluble salts in soil negatively affect the mineralization and nitrification processes, imposing various effects on $\mathrm{N}_{2} \mathrm{O}$ emission of soils $[25,26]$. In the present study, two drought- and salt-tolerant C3 (i.e., barley and rye) and C4 species (i.e., sorghum hybrid sudangrass and corngrass) were selected and planted in salinization fields of an inland arid region, and soil properties, soil $\mathrm{N}_{2} \mathrm{O}$ flux, and forage productivity of these grass fields were measured. Greenhouse gas emission intensity (GEI, GHG flux per unit crop yield) has been used to compare the GHG emissions to produce the same crop yield [27-29]. A number of researchers agree that GEI can assist in solving the global challenges of increasing crop production and concomitantly identifying the main targets for GHG mitigations in different cropping systems, which is important when seeking ways to decrease total GHG emissions associated with agricultural production, especially in China [30]. Based on the above statement, we hypothesize that the grass species with higher $\mathrm{N}$ uptake for soil (i.e., crude protein yield) emits lower $\mathrm{N}_{2} \mathrm{O}$ by decreasing the soil available $\mathrm{N}$ concentration. The purposes of our study are to clarify the mechanisms of soil $\mathrm{N}_{2} \mathrm{O}$ emission in $\mathrm{C} 3$ and $\mathrm{C} 4$ grass fields, and to determine the appropriate grass species with low yield-scaled $\mathrm{N}_{2} \mathrm{O}$ emission in salinization fields of arid region. Our study will contribute to the achievement of sustainable herbivore agriculture and the transfer of arid farm system toward lower $\mathrm{N}$ emissions.

\section{Materials and Methods}

\subsection{Climate and Soil}

The field experiments were performed in 2016 and 2017 at the Linze Grassland Agricultural Trial Station of Lanzhou University, Linze County, Zhangye City and Gansu Province, China. The experimental site is located at latitude $39^{\circ} 15^{\prime}$ and longitude $100^{\circ} 02^{\prime} \mathrm{E}$ at an elevation of $1390 \mathrm{~m}$ above sea level. The northwest inland arid area of the research station is a secondary salinization meadow with temperate continental climate. The average annual temperature is $7.6^{\circ} \mathrm{C}$ and the average hour of sunshine is $3042 \mathrm{~h} / \mathrm{yr}$. There is a frost-free period of approximately 180 days/year and an average annual mean rainfall of $121 \mathrm{~mm} \mathrm{yr}^{-1}$, with over $60 \%$ of the rainfall occurring in summer and fall. The average annual free water evaporation is $2430 \mathrm{~mm}$. The amount of precipitation was $50 \mathrm{~mm}$ in 2016 and $87 \mathrm{~mm}$ in 2017. The monthly precipitation during the experimental years is shown in Figure 1. The soil in the research site is classified as Aquisalids according to USDA soil taxonomy (salt $0.7-0.9 \%$ ). Before experiment, the initial soil properties measured at $30 \mathrm{~cm}$ soil depth were: soil organ carbon $9.34 \mathrm{~g} / \mathrm{kg}$, total $\mathrm{N} 1.07 \mathrm{~g} / \mathrm{kg}$, pH 8.5, bulk density $0.93 \mathrm{~g} / \mathrm{cm}^{3}$. 


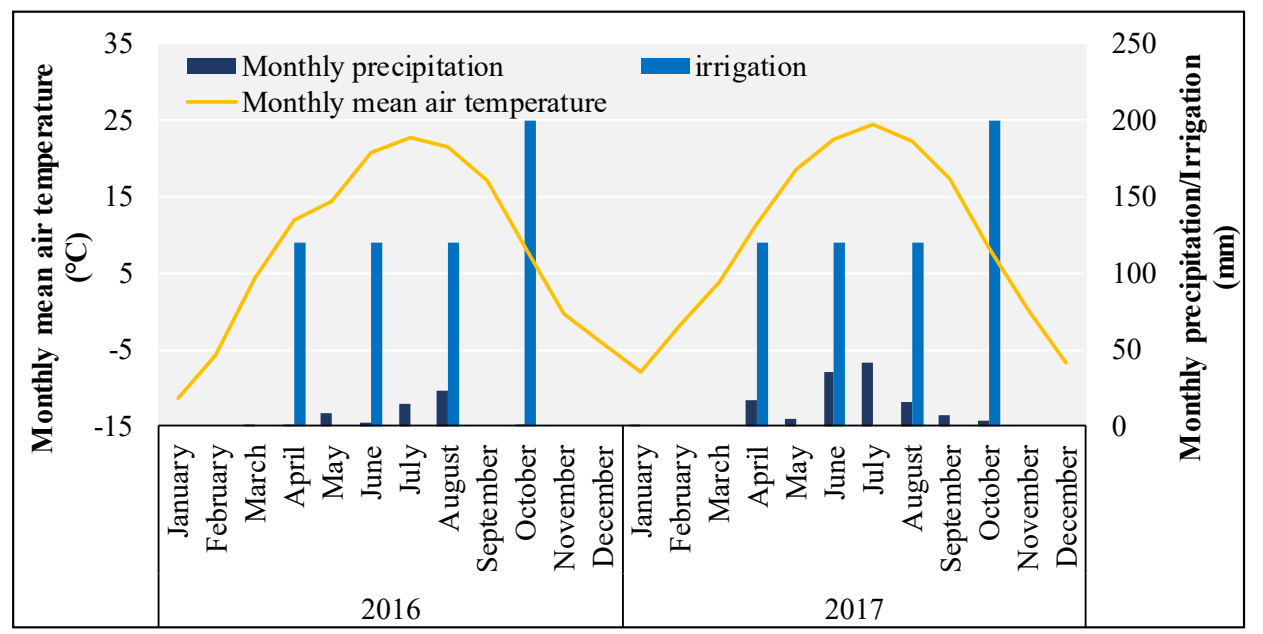

Figure 1. The air temperature, precipitation, and irrigation of study site in 2016 and 2017.

\subsection{Experimental Design}

Two C4 grass species, sorghum hybrid sudangrass (SHS, Sorghum bicolor $\times$ S. sudanenese) and corngrass I (Zea mays $\times$ Zea mexicana), and two C3 grass species, barley (Hordeum vulgare L.) and rye (Secale cereale L.) were chosen to establish plots for measuring $\mathrm{N}_{2} \mathrm{O}$ emission and forage yield. This study was conducted with a randomized complete block design with three replications (plots) for each grass species. The length and width of each plot were $15 \mathrm{~m}$ and $6 \mathrm{~m}$, respectively (area $=90 \mathrm{~m}^{2}$ ), and a 1.5-m-wide isolation belt and a ridge were placed between each plot to prevent nutrient and water leakage. Traditional flat planting of $50 \mathrm{~cm}$ in width was used for the two C4 species with different seeding spacing ( $25 \mathrm{~cm}$ for corngrass and $20 \mathrm{~cm}$ for SHS) and evaluated density (82,500 plants/ha corngrass and 10,500 plants/ha for SHS). Broadcasting sowing was used for barley and rye with a seeding rate of $375 \mathrm{~kg} / \mathrm{ha}$ and $300 \mathrm{~kg} / \mathrm{ha}$, respectively.

Forages were sown on 20 May 2016 and 24 May 2017 due to the local unstable weather condition (e.g., air temperature declining suddenly) in spring and no cold tolerance of chosen $\mathrm{C} 4$ species, using a hole-sowing machine with a seeding depth of $3-4 \mathrm{~cm}$ and manual broadcasting sower. A base fertilizer containing $150 \mathrm{~kg} / \mathrm{ha} \mathrm{P}_{2} \mathrm{O}_{5}$ was spread evenly over the furrow. Irrigation (about $120 \mathrm{~mm}$ ) was applied twice during growing season (Table 1). The corngrass and SHS were harvested three times per year at the stubble height of $15 \mathrm{~cm}$, while the plant heights were 100-130 cm and 130-160 cm for corngrass and SHS, respectively. Barley and rye also were harvested three times per year at the stubble height of $5 \mathrm{~cm}$, while the plant grew to $25-30 \mathrm{~cm}$. The schedule for harvests was listed in Table 1 . Weeds were controlled manually during each growing season.

Table 1. The schematic timeline of the $\mathrm{N}_{2} \mathrm{O}$ flux measurements, irrigation events and harvests for $\mathrm{C} 3$ and C4 grass species.

\begin{tabular}{ccccc}
\hline \multirow{2}{*}{ Items } & \multicolumn{2}{c}{2016} & \multicolumn{2}{c}{2017} \\
\cline { 2 - 5 } & C3 & C4 & C3 & C4 \\
& 21-23 May & 21-23 May & 25-27 May & 25-27 May \\
$\mathrm{N}_{2}$ O flux & 20-22 June & 20-22 June & 26-28 June & 26-28 June \\
measurement & 18-20 July & 18-20 July & 19-21 July & 19-21 July \\
& 21-23 August & 21-23 August & 21-23 August & 21-23 August \\
& 25-27 September & 25-27 September & 27-29 September & 27-29 September \\
\hline \multirow{2}{*}{ Irrigation } & 28 June & 28 June & 30 June & 30 June \\
& 10 August & 10 August & 12 August & 12 August \\
\hline \multirow{3}{*}{ Harvest } & 26 July & 20 July & 28 July & 23 July \\
& 24 August & 17 August & 25 August & 20 August \\
& 26 September & 20 September & 28 September & 22 September \\
\hline
\end{tabular}




\subsection{Sampling and Measurements}

\subsubsection{Nitrous Oxide $\left(\mathrm{N}_{2} \mathrm{O}\right)$}

Three successive sunny days avoiding the irrigation and harvest events in each month during growing season were chosen for measuring the $\mathrm{N}_{2} \mathrm{O}$ emission, and the specific times were listed in Table 1.

Measurement of $\mathrm{N}_{2} \mathrm{O}$ was carried out once at 9:00-11:00 of each chosen day in each plot. A static opaque chamber was used to sample $\mathrm{N}_{2} \mathrm{O}$ in each plot. The static opaque chamber $(30 \mathrm{~cm} \times 30 \mathrm{~cm} \times$ $30 \mathrm{~cm}$ ) was constructed from stainless steel and sheathed with 2-cm-thick foam plastic for improving temperature stability. It was fitted with an internal battery-operated fan to mix the air and with a silica gel catheter ( $2 \mathrm{~mm}$ diameter $\times 200 \mathrm{~mm}$ length) on the top of chamber for gas sampling. Gas samples were drawn through a three-way stopcock, using a 50-mL plastic syringe, and then transferred into 300-mL aluminum foil gas-collecting bags. For each sampling event, four gas samples of approximately $300 \mathrm{~mL}$ were taken at time interval of $10 \mathrm{~min}$ (i.e., $0,10,20$, and $30 \mathrm{~min}$ ). The chamber was also equipped with an electronic thermometer. The temperature inside the chamber was recorded during gas sampling and applied to calculate gas flux; soil temperature (ST) was also measured by a mercurial thermometer inserted $5 \mathrm{~cm}$ into the soil at the sampling site before and after gas sampling and the mean temperature was applied to detect its effect on GHG emissions.

Samples were brought back to the laboratory, and gas concentration was measured within $24 \mathrm{~h}$ by a $\mathrm{N}_{2} \mathrm{O}$ analyzer (Model No. 908-0015-0000, Los Gatos Research, San Jose, CA, USA). The exchange flux of $\mathrm{N}_{2} \mathrm{O}$ describes the change of gases in unit time in the sampling box, which was calculated according to Liu et al. [31] and Ning et al. [32]. The total $\mathrm{N}_{2} \mathrm{O}$ flux in growing season was calculated according to Ning et al. (2020) [32]: total $\mathrm{N}_{2} \mathrm{O}$ flux $=$ mean daily $\mathrm{N}_{2} \mathrm{O}$ flux $\times$ test days. $\mathrm{N}_{2} \mathrm{O}$ emission intensity (NEI) measuring the $\mathrm{N}_{2} \mathrm{O}$ flux per unit hay yield ( $\mathrm{NEI}_{\text {hay }}$ ) and per unit crude protein yield $\left(\mathrm{NEI}_{\mathrm{CP}}\right)$ was estimated according to Dyer et al. [33].

\subsubsection{Forage Yield and Soil Property}

To determine the forage yield, three quadrats $(50 \mathrm{~cm} \times 50 \mathrm{~cm})$ were set up in each plot for each C3 species, and eight typical plants of each $\mathrm{C} 4$ species were randomly selected in each plot, and then these fresh grasses mowed were oven dry for a minimum of $48 \mathrm{~h}$. After weighting, the forage samples were smashed and extracted by passing through a $0.25-\mathrm{mm}$ sieve, then the $\mathrm{CP}$ was measured by Kjeldahl method [34].

Three sites in each plot were randomly selected for collecting soil at a $0-15 \mathrm{~cm}$ depth using the bucket auger ( $5 \mathrm{~cm}$ diameter) after each $\mathrm{N}_{2} \mathrm{O}$ collection. The soil water content (SWC) was estimated as: (original wet weight - soil dry weight)/original dry weight $\times 100 \%$. Part of fresh soil was used to measure soil available nitrogen (SAN) $\left(\mathrm{NH}_{4}{ }^{+}-\mathrm{N}\right.$ and $\left.\mathrm{NO}_{3}{ }^{-}-\mathrm{N}\right)$ by colorimetric method [35]. The other part of soil samples was air-dried then ground through a $0.25-\mathrm{mm}$ sieve. Soil organic carbon (SOC) was measured by chromic acid REDOX titration [36], soil pH ( $\mathrm{SpH}$ ) was measured by potential method [37], and soil total nitrogen (STN) was determined by following the methods of Bremner and Mulvaney [34].

\subsection{Statistical Analysis}

All other statistical analyses were conducted using SAS 9.4 (SAS Institute Inc., Cary, NC, USA). Results of a Shapiro-Wilk test (UNIVARIATE Procedure) indicated that data collected from this study were normally distributed. As the interactions between year and species were not significantly different, a one-way ANOVA (GLM Procedure) was applied to compare the mean difference in soil $\mathrm{N}_{2} \mathrm{O}$ flux between months or between species (Figures 2 and 3), and that in forage production between species (Figure 5), with a least significant difference (LSD) test for multiple comparisons. $\mathrm{N}_{2} \mathrm{O}$ flux in relation to each soil property (Figure 4) was determined for each species using a linear regression (GLM Procedure). As there was no significant difference in soil properties and $\mathrm{N}_{2} \mathrm{O}$ flux between 2016 and 2017, data were pooled before analyses. The regression slopes of different species were 
compared using an analysis of covariance (ANCOVA, GLM Procedure) with a CONTRAST statement for pairwise comparison. As there was no significant difference in slope between the two C3 or C4 species, we also determined the relationships between $\mathrm{N}_{2} \mathrm{O}$ flux and soil properties for the $\mathrm{C} 3$ and C4 species (Figure 4; Tables 2 and 3). A multiple variate linear regression was used to test the soil properties affecting the $\mathrm{N}_{2} \mathrm{O}$ flux, while only the significant factors (properties) remained in the final optimal model (Table 4).

\section{Results}

\subsection{Soil $\mathrm{N}_{2} \mathrm{O}$ Emission in Barley, Rye, Corngrass, and SHS}

For each species, soil $\mathrm{N}_{2} \mathrm{O}$ fluxes significantly increased from early growing season (May) to mid-growing season (July), then significantly decreased $(P<0.05)$ (Figure 2). Soil $\mathrm{N}_{2} \mathrm{O}$ flux from SHS field $\left(\mathrm{N}_{2} \mathrm{O}\right.$ flux $=22.3$ and $16.2 \mu \mathrm{g} / \mathrm{m}^{2} / \mathrm{h}$, respectively for June and September) was significantly greater than that from barley field $\left(\mathrm{N}_{2} \mathrm{O}\right.$ flux $=16.4$ and 8.3, respectively for June and September) in June and September in $2016(P<0.05)$ (Figure $2 \mathrm{~A})$, and soil $\mathrm{N}_{2} \mathrm{O}$ fluxes from corngrass $\left(22.8 \mu \mathrm{g} / \mathrm{m}^{2} / \mathrm{h}\right)$ and SHS $\left(22.3 \mu \mathrm{g} / \mathrm{m}^{2} / \mathrm{h}\right)$ were significantly greater than that from rye $\left(16.8 \mu \mathrm{g} / \mathrm{m}^{2} / \mathrm{h}\right)$ in June of $2017(P<0.05)$ (Figure 2B).

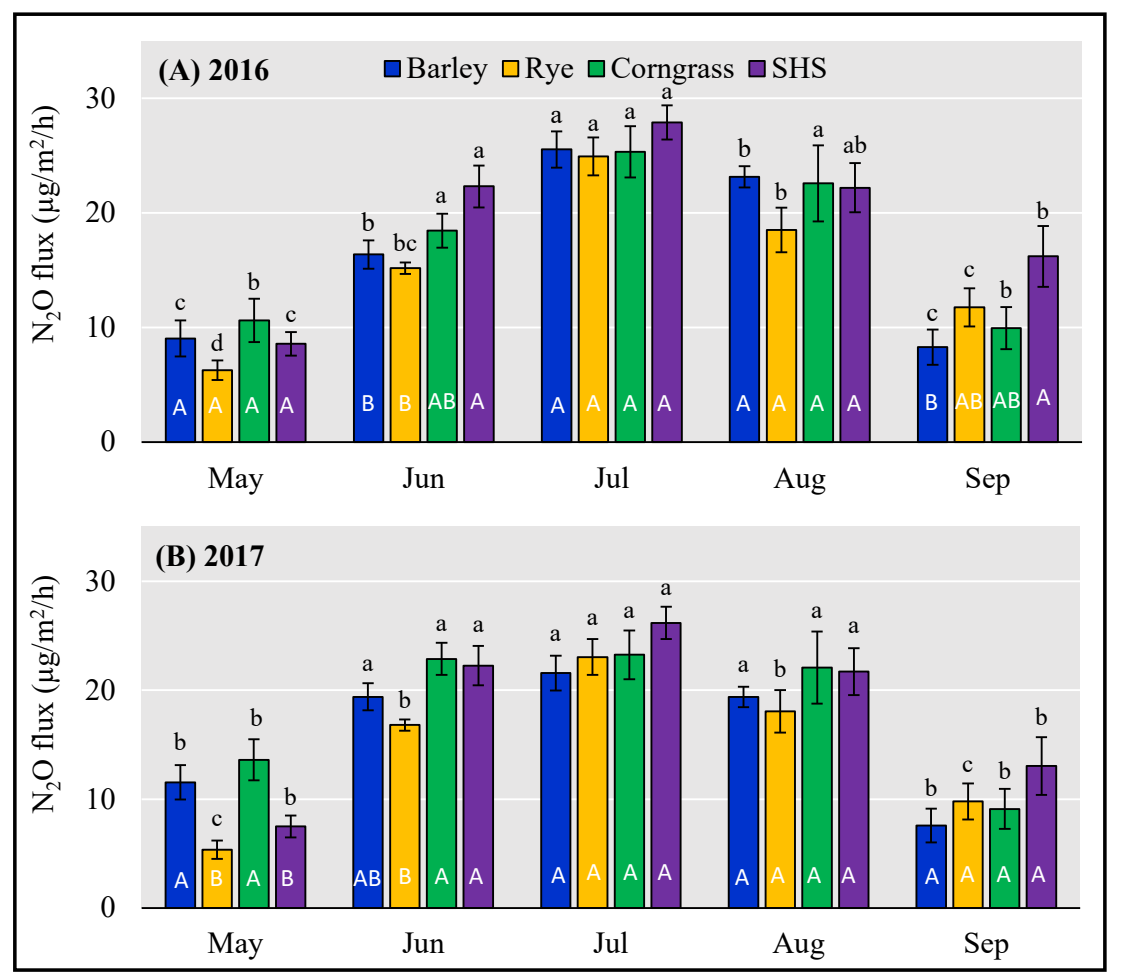

Figure 2. The dynamics of soil $\mathrm{N}_{2} \mathrm{O}$ emission in 2016 (A) and 2017 (B) in barley, rye, sorghum hybrid sudangrass (SHS), and corngrass fields. For each species, means with the same lowercase letters are not significantly different between different months $(P>0.05)$; for each month, means with the same uppercase letters are not significantly different between different grass species $(P>0.05)$.

The total soil $\mathrm{N}_{2} \mathrm{O}$ quantities during the growing seasons were significantly greater from SHS than from rye in $2016(P<0.05)$ and significantly greater from SHS and corngrass than from rye in 2017 $(P<0.05)$ (Figure 3). The total soil $\mathrm{N}_{2} \mathrm{O}$ quantity in $\mathrm{C} 3$ fields during the growing seasons was $15.08 \%$ lower compared to that in $\mathrm{C} 4$ fields. 


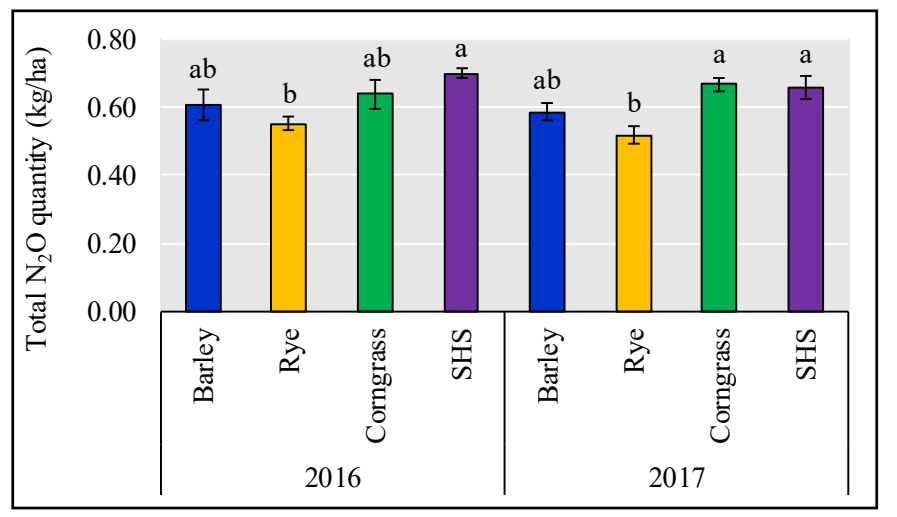

Figure 3. The total soil $\mathrm{N}_{2} \mathrm{O}$ flux from barley, rye, $\mathrm{SHS}$, and corngrass fields during growing seasons in 2016 and 2017. Means with the same letters are not significantly different $(P>0.05)$.

\subsection{Soil $\mathrm{N}_{2} \mathrm{O}$ Emission in Relation to Soil Property}

Increasing soil temperature, organic carbon, $\mathrm{pH}$, available nitrogen, and total nitrogen was significantly promoted, but increasing soil water content significantly decreased $\mathrm{N}_{2} \mathrm{O}$ emissions $(P<0.05)$, except that soil organic carbon did not have a significant effect on $\mathrm{N}_{2} \mathrm{O}$ emission from barley (Figure 4, Table 2). For a given soil property, the regression slope was not significantly different between barley and rye or between corngrass and SHS $(P>0.05)$. The soil temperature, water content, organic carbon, $\mathrm{pH}$, available nitrogen, and total nitrogen respectively explained $69.37 \%, 76.03 \%$, $22.54 \%, 70.26 \%, 74.00 \%$, and $35.55 \%$ variation of $\mathrm{N}_{2} \mathrm{O}$ emission from $\mathrm{C} 3$ species and $74.48 \%, 66.09 \%$, $38.10 \%, 66.45 \%, 70.26 \%$, and $18.78 \%$ variation of $\mathrm{N}_{2} \mathrm{O}$ emission from $\mathrm{C} 4$ species (Figure 4, Table 3). $\mathrm{N}_{2} \mathrm{O}$ emission increased significantly faster with increasing ST in C4 fields than in C3 fields $(P=0.0083)$.

Table 2. Summary of linear regressions (Figure 3) between soil $\mathrm{N}_{2} \mathrm{O}$ fluxes and soil properties: soil temperature (ST), soil water content (SWC), soil organic carbon (SOC), soil pH ( $\mathrm{SpH}$ ), soil available nitrogen (SAT), and soil total nitrogen (STN) in barley, rye, corngrass, and SHS fields. For each soil property, slopes with the same letters are not significantly different between species $(P>0.05)$.

\begin{tabular}{ccccccccccc}
\hline Species & Intercept & Slope & $\boldsymbol{R}^{\mathbf{2}}$ & $\boldsymbol{F}_{\mathbf{( 1 , 2 8 )}}$ & $\boldsymbol{P}$ & Intercept & Slope & $\boldsymbol{R}^{\mathbf{2}}$ & $\boldsymbol{F}_{\mathbf{( 1 , 2 8 )}}$ & $\boldsymbol{P}$ \\
\hline \multicolumn{1}{c}{ ST } \\
\hline Barley & -0.15 & $0.91 \mathrm{a}$ & 0.6856 & 61.05 & $<0.0001$ & 45.00 & $-0.94 \mathrm{a}$ & 0.8154 & 123.71 & $<0.0001$ \\
Rye & -1.24 & $0.98 \mathrm{a}$ & 0.7377 & 78.75 & $<0.0001$ & 42.73 & $-0.89 \mathrm{a}$ & 0.7083 & 68.00 & $<0.0001$ \\
Corngrass & -2.17 & $1.17 \mathrm{a}$ & 0.7522 & 85.00 & $<0.0001$ & 42.83 & $-0.86 \mathrm{a}$ & 0.7434 & 81.11 & $<0.0001$ \\
SHS & -3.03 & $1.23 \mathrm{a}$ & 0.7375 & 78.67 & $<0.0001$ & 44.86 & $-0.88 \mathrm{a}$ & 0.6087 & 43.56 & $<0.0001$ \\
\hline & SOC & & & & & SpH & & & & \\
\hline Barley & -98.78 & $12.30 \mathrm{a}$ & 0.1203 & 3.83 & 0.0604 & -164.39 & $23.46 \mathrm{a}$ & 0.6209 & 45.68 & $<0.0001$ \\
Rye & -150.96 & $17.56 \mathrm{a}$ & 0.4184 & 20.14 & 0.0001 & -159.61 & $22.74 \mathrm{a}$ & 0.7868 & 103.30 & $<0.0001$ \\
Corngrass & -197.85 & $23.03 \mathrm{a}$ & 0.2747 & 10.60 & 0.0030 & -164.64 & $23.67 \mathrm{a}$ & 0.6291 & 47.49 & $<0.0001$ \\
SHS & -63.57 & $19.30 \mathrm{a}$ & 0.4734 & 25.17 & $<0.0001$ & -162.71 & $23.61 \mathrm{a}$ & 0.7095 & 68.39 & $<0.0001$ \\
\hline & $\mathbf{S A N}$ & & & & & STN & & & & \\
\hline Barley & -7.90 & $0.56 \mathrm{~b}$ & 0.8181 & 125.96 & $<0.0001$ & -15.90 & $24.78 \mathrm{a}$ & 0.3444 & 14.71 & 0.0007 \\
Rye & -13.02 & $0.71 \mathrm{ab}$ & 0.6806 & 59.66 & $<0.0001$ & -21.17 & $30.36 \mathrm{a}$ & 0.3899 & 17.90 & 0.0002 \\
Corngrass & -9.60 & $0.61 \mathrm{ab}$ & 0.8651 & 79.31 & $<0.0001$ & -10.32 & $22.07 \mathrm{a}$ & 0.2064 & 7.20 & 0.0121 \\
SHS & -15.64 & $0.83 \mathrm{a}$ & 0.7490 & 83.56 & $<0.0001$ & -20.39 & $33.08 \mathrm{a}$ & 0.2845 & 11.13 & 0.0024 \\
\hline
\end{tabular}


Table 3. Summary of linear regressions (Figure 3) between soil $\mathrm{N}_{2} \mathrm{O}$ fluxes and soil properties: soil temperature (ST), soil water content (SWC), soil organic carbon (SOC), soil pH (SpH), soil available nitrogen (SAT), and soil total nitrogen (STN) in C3 and C4 species. For each soil property, slopes with the same letters are not significantly different between $C 3$ and $C 4$ species $(P>0.05)$.

\begin{tabular}{|c|c|c|c|c|c|c|c|c|c|c|}
\hline Species & Intercept & Slope & $R^{2}$ & $F_{(1,28)}$ & $P$ & Intercept & Slope & $R^{2}$ & $F_{(1,58)}$ & $P$ \\
\hline & ST & & & & & SWC & & & & \\
\hline $\mathrm{C} 3$ & -0.51 & $0.88 \mathrm{~b}$ & 0.6937 & 131.33 & $<0.0001$ & 43.96 & $-0.92 a$ & 0.7604 & 194.01 & $<0.0001$ \\
\hline \multirow[t]{2}{*}{$\mathrm{C} 4$} & -2.63 & $1.20 \mathrm{a}$ & 0.7448 & 169.30 & $<0.0001$ & 43.70 & $-0.86 \mathrm{a}$ & 0.6609 & 113.03 & $<0.0001$ \\
\hline & SOC & & & & & $\mathrm{SpH}$ & & & & \\
\hline C3 & -117.47 & $14.15 \mathrm{a}$ & 0.2254 & 16.88 & $<0.0001$ & -162.10 & $23.11 \mathrm{a}$ & 0.7026 & 137.00 & $<0.0001$ \\
\hline \multirow[t]{2}{*}{$\mathrm{C} 4$} & -169.18 & $19.93 \mathrm{a}$ & 0.3810 & 35.70 & $<0.0001$ & -162.86 & $23.51 \mathrm{a}$ & 0.6645 & 114.87 & $<0.0001$ \\
\hline & SAN & & & & & STN & & & & \\
\hline $\mathrm{C} 3$ & -9.40 & $0.61 \mathrm{a}$ & 0.7400 & 165.08 & $<0.0001$ & -16.03 & $25.42 \mathrm{a}$ & 0.3555 & 31.99 & $<0.0001$ \\
\hline $\mathrm{C} 4$ & -10.06 & $0.66 \mathrm{a}$ & 0.7315 & 158.04 & $<0.0001$ & -9.91 & $22.39 a$ & 0.1878 & 19.41 & 0.0005 \\
\hline
\end{tabular}

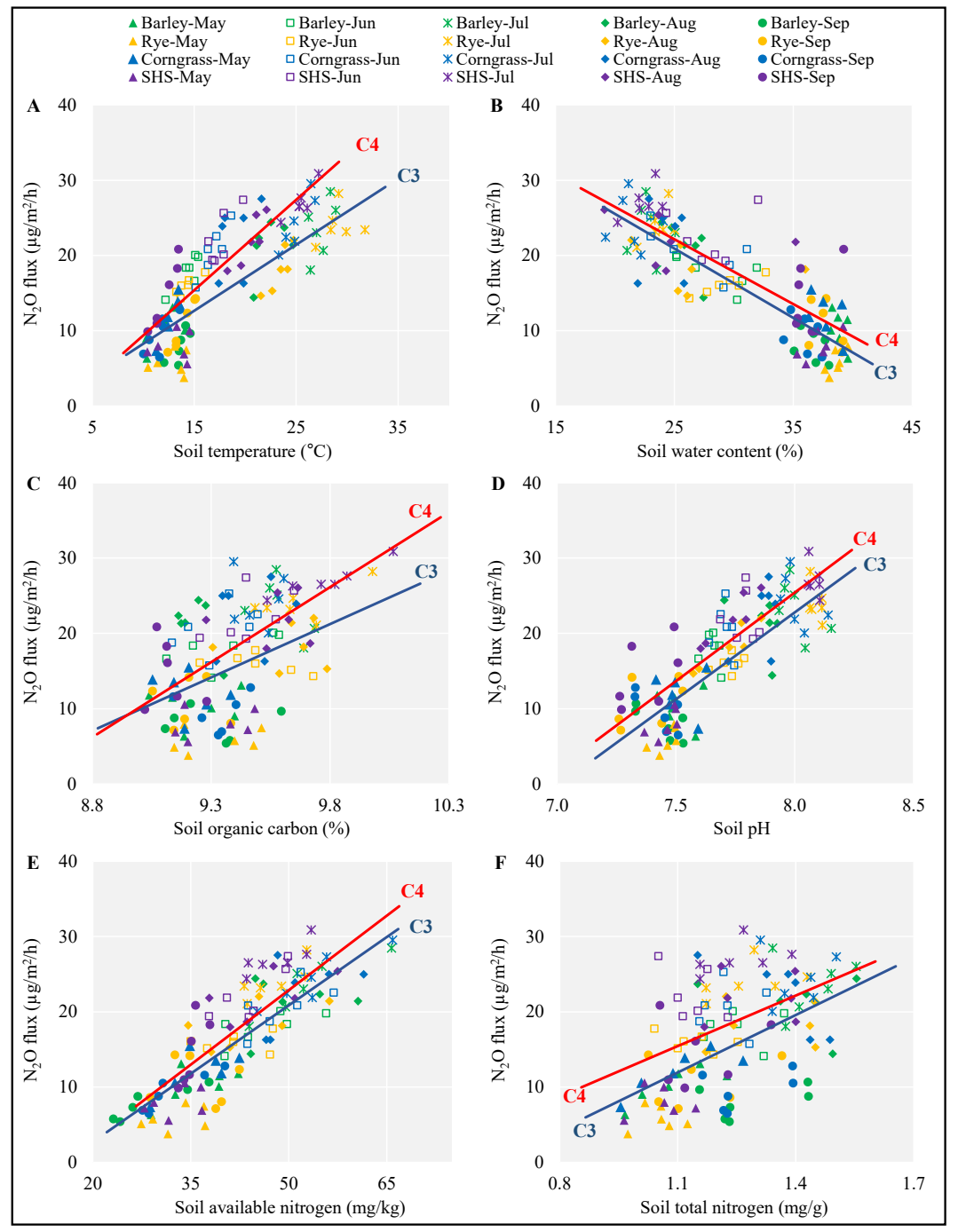

Figure 4. The linear regressions between soil $\mathrm{N}_{2} \mathrm{O}$ fluxes and soil properties of soil temperature (A), soil water content (B), soil organic carbon (C), soil pH (D), soil available nitrogen (E), and soil total nitrogen (F) in barley, rye, corngrass, and SHS fields. The statistical results are summarized in Table 2 for each species and in Table 3 for C3 and C4 species. 
Amount soil properties, soil available nitrogen, soil water content, and soil temperature were the main factors that significantly affected $\mathrm{N}_{2} \mathrm{O}$ fluxes and explained $88.23 \%$ variation of $\mathrm{N}_{2} \mathrm{O}$ fluxes in C3 fields (Table 1); while only two factors (i.e., soil available nitrogen and temperature) significantly affected $\mathrm{N}_{2} \mathrm{O}$ flux and explained $82.55 \%$ variation of $\mathrm{N}_{2} \mathrm{O}$ flux in $\mathrm{C} 4$ field. Soil-available nitrogen accounted for $\geq 70 \%$ variation of $\mathrm{N}_{2} \mathrm{O}$ fluxes for both field types (Table 4 ).

Table 4. The most parsimonious multiple linear regression model including soil available nitrogen (SAN, $\mathrm{mg} / \mathrm{kg}$ ), soil temperature $\left(\mathrm{ST},{ }^{\circ} \mathrm{C}\right.$ ) or soil water content $\left(\mathrm{SWC}, \mathrm{g} / \mathrm{cm}^{3}\right)$, and their contributions to $\mathrm{N}_{2} \mathrm{O}$ flux $\left(\mu \mathrm{g} / \mathrm{m}^{2} / \mathrm{h}\right)$ during growing seasons in $\mathrm{C} 3$ and $\mathrm{C} 4$ fields.

\begin{tabular}{ccccccc}
\hline Species & Factor & df & Type I SS & Contribution (\%) & $\boldsymbol{F}$ & $\boldsymbol{P}$ \\
\hline $\mathrm{C} 3$ & SAN & 1 & 1971.21 & 74.00 & 352.00 & $<0.0001$ \\
& SWC & 1 & 325.30 & 12.21 & 58.09 & $<0.0001$ \\
& ST & 1 & 53.90 & 2.02 & 9.59 & 0.0031 \\
& Error & 56 & 313.60 & 11.77 & & \\
\hline C4 & Final model: $\mathrm{N}_{2} \mathrm{O}$ flux $=10.06+0.30 \mathrm{AN}-0.38 \mathrm{SWC}+0.26 \mathrm{ST}\left(R^{2}=0.8823\right)$ & \\
& SAN & 1 & 2157.26 & 73.15 & 238.93 & $<0.0001$ \\
& ST & 1 & 277.07 & 9.40 & 30.69 & $<0.0001$ \\
& Error & 57 & 514.64 & 17.45 & &
\end{tabular}

\subsection{Soil $\mathrm{N}_{2} \mathrm{O}$ Emission and Forage Production}

The hay and crude protein yields of SHS were significantly greater than that of corngrass in 2016 and 2017, and both were significantly greater than that of barley and rye $(P<0.05)$ (Figure 5A,B). The total hay and crude protein yields of $C 4$ species were, respectively, 1.61 and 1.37 times greater than that of $\mathrm{C} 3$ species. The $\mathrm{NEI}_{\text {hay }}$ and $\mathrm{NEI}_{\mathrm{CP}}$ were significantly lower in corngrass and SHS than in barley in 2016 and 2017, and significantly lower in SHS than in corngrass and in rye than in barley in 2017 $(P<0.05)$ (Figure $5 \mathrm{C}, \mathrm{D})$. The $\mathrm{NEI}_{\text {hay }}$ and $\mathrm{NEI}_{\mathrm{CP}}$ of $\mathrm{C} 4$ species were, respectively, $26.50 \%$ and $13.44 \%$ lower than that of $\mathrm{C} 3$ species.

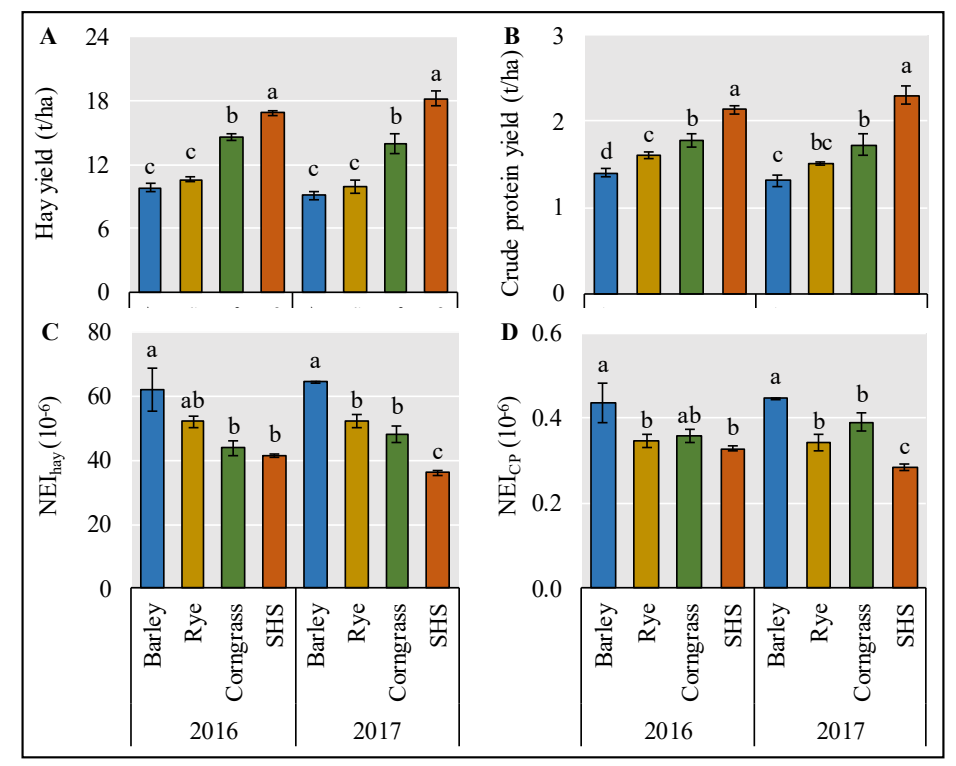

Figure 5. Mean $\left( \pm \mathrm{SE}\right.$ ) hay yield (A), crude protein yield $(\mathbf{B}), \mathrm{NEI}_{\text {hay }}(\mathbf{C})$, and $\mathrm{NEI}_{\mathrm{CP}}(\mathbf{D})\left(\mathrm{N}_{2} \mathrm{O}\right.$ emission intensity, i.e., yield-scaled $\mathrm{N}_{2} \mathrm{O}$ emission) for barley, rye, corngrass, and SHS in 2016 and 2017. For each category and each year, means with the same letters are not significantly different $(P>0.05)$. 


\section{Discussion}

When soil-available $\mathrm{N}$ is large, a great plant $\mathrm{N}$ capture will reduce soil mineral availability, substrate for denitrifiers, and the abundance of nitrate-reducing microorganisms, which will increase soil $\mathrm{N}_{2} \mathrm{O}$ emission $[20,38,39]$. Therefore, the productivity of biomass and crude protein are the critical factors regulating plant-soil interactions in terms of $\mathrm{N}_{2} \mathrm{O}$ emission [19]. However, there were contrasting results between $\mathrm{C} 3$ and $\mathrm{C} 4$ grasses, i.e., $\mathrm{C} 4$ grass species had a relatively higher soil $\mathrm{N}_{2} \mathrm{O}$ flux and higher crude protein and biomass yields than $\mathrm{C} 3$ species (Figures 3 and $5 \mathrm{~B}$ ). These discrepancies were probably because of species particularities and the limited soil $\mathrm{N}$ concentration. $\mathrm{C} 4$ grass species (such as the corngrass and SHS in the study) require more water, which may cause soil temperature to be more sensitive to the change of sunshine, while soil temperature is positively correlated with $\mathrm{N}_{2} \mathrm{O}$ emission $[40,41]$. Meanwhile, the competitions of soil microbial communities in high-N soil are more effective for $\mathrm{N}$ source than that in in low- $\mathrm{N}$ soil $[42,43]$. Therefore, it is likely that grass species with great water requirement moderate $\mathrm{N}_{2} \mathrm{O}$ emission by decreasing soil temperature and enhancing the $\mathrm{N}$ competitions of soil microbes instead of controlling $\mathrm{N}$ uptake and then diminishing the abundance or activity of soil microbes in low-available-N or no-N-addition soils. Our results show that soil-available $\mathrm{N}$ explained $>70 \%$ variance of soil $\mathrm{N}_{2} \mathrm{O}$ emission, and the sensitivities of soil $\mathrm{N}_{2} \mathrm{O}$ emission to available $\mathrm{N}$ between $\mathrm{C} 3$ and $\mathrm{C} 4$ species was not significantly different (Table 3). Soil-available $\mathrm{N}$ contributed greater impact to $\mathrm{N}_{2} \mathrm{O}$ emission than soil temperature and soil water content (Table 4). Fertilizing $\mathrm{N}$ significantly increases soil $\mathrm{N}_{2} \mathrm{O}$ emission because it actually increases the soil-available $\mathrm{N}$ as a substrate for nitrification and denitrification [29]. Our results prove again that available $\mathrm{N}$ is the most important factor that directly reflects the soil $\mathrm{N}_{2} \mathrm{O}$ emission no matter what type of grass species is used in the land $[15,29]$.

The most parsimonious multiple linear regression model unraveled the two most important factors, beside available $\mathrm{N}$, as the key predictors of $\mathrm{N}_{2} \mathrm{O}$ emission, the soil temperature and soil water content (Table 4). Soil temperature is the major driver regulating soil $\mathrm{N}_{2} \mathrm{O}$ fluxes mainly via soil respiration and microbial activity [16-18]. As reported in studies on $\mathrm{N}_{2} \mathrm{O}$ fluxes in sorghum and wheat fields in arid region $[40,41]$, we found that increasing soil temperature elevated $\mathrm{N}_{2} \mathrm{O}$ fluxes (Figure 4). These results agree with the general conclusions of previous studies [16-18,44]. Therefore, it may be prevalent that $\mathrm{N}_{2} \mathrm{O}$ fluxes start to increase in spring (May) and peak in summer (July) (Figure 2A,B), because the soil warming promotes microbial activity $[16,17]$. In the inland arid region of northwest China, the optimum water requirement for wheat is $414 \mathrm{~mm}$, which is less than that for corn (e.g., $570 \mathrm{~mm}$ ) [42]. Grass species have different water requirements, and nutrient use efficiency is likely to have an effect on soil properties including soil temperature [4,5], and then to vary the richness and diversity of microbes regulating soil $\mathrm{N}_{2} \mathrm{O}$ emission [43,44]. The greater richness and diversity of microbes in $\mathrm{C} 4$ grass fields is likely to result in the higher sensitivity of soil $\mathrm{N}_{2} \mathrm{O}$ emission to soil temperature in $\mathrm{C} 4$ than in $\mathrm{C} 3$ grass fields (Table 3).

Contrary to other findings [45,46], a significantly negative impact of soil water content on soil $\mathrm{N}_{2} \mathrm{O}$ emission was detected in the study (Figure 4). A greater soil water content may be beneficial for microbe-regulating soil $\mathrm{N}_{2} \mathrm{O}$ emission $[38,39]$. However, it also activates soluble salts in soil that negatively affects the mineralization and nitrification. In fact, soil water content influences $\mathrm{N}_{2} \mathrm{O}$ flux via changing gas diffusion rate and oxygen availability or regulating microbial communities because they require water for physiological activities [17]. However, different soil types may have specific soil moisture to optimize $\mathrm{N}_{2} \mathrm{O}$ flux [47]. $\mathrm{N}_{2} \mathrm{O}$ transport is restricted when moisture exceeds the optimum level $[48,49]$ leading to anaerobic conditions, whereas suboptimal moisture levels will limit $\mathrm{N}_{2} \mathrm{O}$ flux due to water stress of soil microbes [16]. In addition, the high soil water content may restrict the soil temperature, which may significantly suppress soil $\mathrm{N}_{2} \mathrm{O}$ emission. Therefore, depending on the region, the change of soil water content may make the soil $\mathrm{N}_{2} \mathrm{O}$ emission absolutely different.

$\mathrm{N}_{2} \mathrm{O}$ emission intensity (NEI, yield-scaled $\mathrm{N}_{2} \mathrm{O}$ emissions, i.e., cumulative emissions divided by hay yield or crude protein yield [28]) gives an effective measure to balance potential trade-offs between food production and environmental sustainability [50]. We found that C4 grass species may 
respectively lead to $26.5 \%$ and $13.4 \%$ reductions on $\mathrm{N}_{2} \mathrm{O}$ emission per unit of hay and crude protein production (Figure 5C,D). In arid regions, traditional annual C3 grass species are planted more in order to release grazing pressure in cool seasons due to its short growing season and abundant biomass. Our study shows that in the current context of widespread C3 grass species use, C4 species should be promoted to develop animal husbandry that retain $\mathrm{N}$ more efficiently and contribute optimally to climate change mitigation. Therefore, improving cultivation of $\mathrm{C} 4$ species will be a huge challenge or an opportunity for future agriculture.

\section{Conclusions}

Our results indicated that in the arid regions with higher soil salt, soil in C4 fields emitted more $\mathrm{N}_{2} \mathrm{O}$ than that in $\mathrm{C} 3$ fields; however, $\mathrm{C} 4$ grass species produced greater hay and crude protein yield with lower hay/crude protein yield-scaled $\mathrm{N}_{2} \mathrm{O}$ emission. Therefore, we may conclude that $\mathrm{C} 4$ species contribute optimally to climate change mitigation in arid regions. We revealed that soil-available $\mathrm{N}$ was the most important factor regulating soil $\mathrm{N}_{2} \mathrm{O}$ flux in both $\mathrm{C} 3$ and $\mathrm{C} 4$ grass fields, and soil temperature and soil water content were the other two key factors. Our results assume that $\mathrm{C} 4$ species with great water requirement moderate $\mathrm{N}_{2} \mathrm{O}$ emission by decreasing soil temperature and enhancing the $\mathrm{N}$ competitions of soil microbes instead of controlling $\mathrm{N}$ uptake and then diminishing the abundance or activity of soil microbes in low available $\mathrm{N}$ or no $\mathrm{N}$ addition soils. Further investigations into this assumption should be conducted in the similar environmental region.

Author Contributions: Conceptualization, F.H.; methodology, J.N.; investigation, J.N.; original draft preparation, J.N. \& F.H.; data analysis, J.N. and X.Z.H.; review and editing, J.N., F.H. \& X.Z.H.; supervision, F.H.; project administration, F.H. All authors have read and agreed to the published version of the manuscript.

Funding: Financial support for this research was provided by Strategic Priority Research Program of Chinese Academy of Science (XDA20100102), National Key Basic Research Program of China (2014CB138706), Changjiang Scholars and Innovative Research Team in University (IRT17R50), and Key R \& D Program of Ningxia Hui Autonomous Region (2019BBF02001).

Acknowledgments: We thank three anonymous reviewers for their constructive comments on the earlier version, which have significantly improved the article.

Conflicts of Interest: The authors declare no conflict of interest. The sponsors had no role in the design, execution, interpretation, or writing of the study.

\section{References}

1. Hou, F.; Nan, Z.; Ren, J. Integrated crop-livestock production system. Acta Prataculturae Sin. 2009, 18, 211-234.

2. China Agriculture Yearbook Editorial Board. China Agriculture Yearbook; China Agriculture Publishing House: Beijing, China, 2011.

3. Kobayashi, N.; Hou, F.; Tsunekawa, A.; Chen, X.; Yan, T.; Ichinohe, T. Effects of substituting alfalfa hay for concentrate on energy utilization and feeding cost of crossbred simmental male calves in Gansu province, China. Grassl. Sci. 2017, 63, 245-254. [CrossRef]

4. Venuto, B.; Kindiger, B. Forage and biomass feedstock production from hybrid forage sorghum and sorghum-sudangrass hybrids. Grassl. Sci. 2008, 54, 189-196. [CrossRef]

5. Lithourgidis, A.S.; Dordas, C.A. Forage yield, growth rate, and nitrogen uptake of faba bean intercrops with wheat, barley, and rye in three seeding ratios. Crop Sci. 2010, 50, 2148-2158. [CrossRef]

6. Perry, M.; Emily, G.; Jeff, H.; Richard, E. Pea and barley forage as fallow replacement for dryland wheat production. Agron. J. 2018, 110, 833-842.

7. Bowatte, S.; Newton, P.C.D.; Theobald, P.; Brock, S.; Chris, H. Emissions of nitrous oxide from the leaves of grasses. Plant Soil 2014, 374, 275-283. [CrossRef]

8. Sage, R.F.; Zhu, X.G. Exploiting the engine of C4 photosynthesis. J. Exp. Bot. 2011, 62, 2989-3000. [CrossRef]

9. Haile, S.G.; Nair, V.D.; Nair, P.K.R. Contribution of trees to carbon storage in soils of silvopastoral systems in Florida, USA. Glob. Chang. Biol. 2010, 16, 427-438. [CrossRef] 
10. Xia, J.; Ren, J.; Zhang, S.; Wang, Y.; Fang, Y. Forest and grass composite patterns improve the soil quality in the coastal saline-alkali land of the yellow river delta, China. Geoderma 2019, 349, 25-35. [CrossRef]

11. Reay, D.S.; Davidson, E.A.; Smith, K.A.; Smith, P.; Melillo, J.M.; Dentener, F.; Crutzen, P.J. Global agriculture and nitrous oxide emissions. Nat. Clim. Chang. 2012, 2, 410-416. [CrossRef]

12. Hillier, J.; Brentrup, F.; Wattenbach, M.; Walter, C.; Garcia-Suarez, T.; Mila-I-Canals, L. Which cropland greenhouse gas mitigation options give the greatest benefits in different world regions? Climate and soil-specific predictions from integrated empirical models. Glob. Chang. Biol. 2012, 18, 1880-1894. [CrossRef]

13. IPCC. Climate change 2007: Synthesis report. In Contribution of Working Groups I, II and III to the Fourth Assessment Report of the Intergovernmental Panel on Climate Change; Pachauri, R.K., Reisinger, A., Eds.; IPCC: Geneva, Switzerland, 2007; pp. 13-42.

14. Ravishankara, A.R.; Daniel, J.S.; Portmann, R.W. Nitrous oxide $\left(\mathrm{N}_{2} \mathrm{O}\right)$ : The dominant ozone-depleting substance emitted in the 21st century. Science 2009, 326, 123-125. [CrossRef] [PubMed]

15. Oertel, C.; Matschullat, J.; Zurba, K.; Zimmermann, F.; Erasmi, S. Greenhouse gas emissions from soils-A review. Chem. Erde-Geochem. 2016, 76, 327-352. [CrossRef]

16. Kitzler, B.; Zechmeister-Boltenstern, S.; Holtermann, C.; Skiba, U.; Butterbach-Bahl, K. Nitrogen oxides emission from two beech forests subjected to different nitrogen loads. Biogeosciences 2006, 3, $293-310$. [CrossRef]

17. Singh, B.K.; Bardgett, R.D.; Smith, P.; Reay, D.S. Microorganisms and climate change: Terrestrial feedbacks and mitigation options. Nat. Rev. Microbiol. 2010, 8, 779-790. [CrossRef] [PubMed]

18. Di, H.J.; Cameron, K.C. Inhibition of nitrification to mitigate nitrate leaching and nitrous oxide emissions in grazed grassland: A review. J. Soils Sediments 2016, 16, 1401-1420. [CrossRef]

19. Abalos, D.; Deyn, D.; Kuyper, T.W.; Van Groenigen, J.W. Plant species identity surpasses species richness as a key driver of $\mathrm{N}_{2} \mathrm{O}$ emissions from grassland. Glob. Chang. Biol. 2014, 20, 265-275. [CrossRef]

20. Abalos, D.; Groenigen, J.W.; De Deyn, G.B. What plant functional traits can reduce nitrous oxide emissions from intensively managed grasslands? Glob. Chang. Biol. 2018, 24, e248-e258. [CrossRef]

21. Fu, S.; Cheng, W.; Susfalk, R. Rhizosphere respiration varies with plant species and phenology: A greenhouse pot experiment. Plant Soil 2002, 239, 133-140. [CrossRef]

22. Zhu, B.; Cheng, W. 13C isotope fractionation during rhizosphere respiration of C3 and C4 plants. Plant Soil 2011, 342, 277-287. [CrossRef]

23. Fassbinder, J.J.; Griffis, T.J.; Baker, J.M. Interannual, seasonal, and diel variability in the carbon isotope composition of respiration in a C3/C4 agricultural ecosystem. Agric. For. Meteorol. 2012, 153, 144-153. [CrossRef]

24. Shrivastava, P.; Kumar, R. Soil salinity: A serious environmental issue and plant growth promoting bacteria as one of the tools for its alleviation. Saudi J. Biol. Sci. 2015, 22, 123-131. [CrossRef] [PubMed]

25. Adviento-Borbe, M.A.A.; Doran, J.W.; Drijber, R.A.; Dobermann, A. Soil electrical conductivity and water content affect nitrous oxide and carbon dioxide emissions in intensively managed soils. J. Environ. Qual. 2006, 35, 1999-2010. [CrossRef] [PubMed]

26. Reddy, N.; Crohn, D.M. Effects of soil salinity and carbon availability from organic amendments on nitrous oxide emissions. Geoderma 2014, 235, 363-371. [CrossRef]

27. Mosier, A.R.; Halvorson, A.D.; Reule, C.A.; Liu, X.J. Net global warming potential and greenhouse gas intensity in irrigated cropping systems in Northeastern Colorado. J. Environ. Qual. 2006, 35, 1584-1598. [CrossRef]

28. Van Groenigen, J.W.; Velthof, G.L.; Oenema, O.; Van Groenigen, K.J.; Van Kessel, C. Towards an agronomic assessment of $\mathrm{N}_{2} \mathrm{O}$ emissions: A case study for arable crops. Eur. J. Soil Sci. 2010, 61, 903-913. [CrossRef]

29. Venterea, R.T.; Hyatt, C.R.; Rosen, C.J. Fertilizer management effects on nitrate leaching and indirect nitrous oxide emissions in irrigated potato production. J. Environ. Qual. 2010, 40, 1103-1112. [CrossRef] [PubMed]

30. Gao, B.; Ju, X.T.; Meng, Q.F.; Cui, Z.L.; Christie, P.; Chen, X.P.; Zhang, F.S. The impact of alternative cropping systems on global warming potential, grain yield and groundwater use. Agric. Ecosyst. Environ. 2015, 203, 46-54. [CrossRef]

31. Liu, Y.; Yan, C.; Matthew, C.; Wood, B.; Hou, F. Key sources and seasonal dynamics of greenhouse gas fluxes from yak grazing systems on the Qinghai-Tibetan Plateau. Sci. Rep. 2017, 7, 40857. [CrossRef]

32. Ning, J.; He, X.Z.; Hou, F.; Lou, S.; Chen, X.; Chang, S.; Zhang, C.; Zhu, W. Optimizing alfalfa productivity and persistence versus greenhouse gases fluxes in a continental arid region. PeerJ 2020, 8, e8738. [CrossRef] 
33. Dyer, J.A.; Vergé, X.P.C.; Desjardins, R.L.; Worth, D.E. The protein-based GHG emission intensity for livestock products in Canada. J. Sustain. Agric. 2010, 34, 618-629. [CrossRef]

34. Schuman, G.E.; Stanley, M.A.; Knudsen, D. Automated total nitrogen analysis of soil and plant samples. Soil Sci. Soc. Am. J. 1973, 37, 480-481. [CrossRef]

35. Risk, N.; Snider, D.; Wagner-Riddle, C. Mechanisms leading to enhanced soil nitrous oxide fluxes induced by freeze-thaw cycles. Can. J. Soil Sci. 2013, 93, 401-414. [CrossRef]

36. Nelson, D.; Sommers, L. Total carbon, organic carbon and organic matter. In Methods of Soil Analysis. Part 3: Chemical Methods, Soil Science Society of America Book Series, Number 5; Sparks, D.L., Page, A.L., Helmke, P.A., Loeppert, R.H., Soltanpour, P.N., Tabatabai, M.A., Johnston, C.T., Sumner, M.E., Eds.; Soil Science Society America: Madison, WI, USA, 1996; pp. 961-1010.

37. McLean, E. Soil pH and Lime Requirement. In Methods of Soil Analysis. Part 2. Chemical and Microbiological Properties; American Society of Agronomy: Madison, WI, USA, 1982; pp. 17-44.

38. De Vries, F.T.; Bardgett, R.D. Plant community controls on short-term ecosystem nitrogen retention. New Phytol. 2010, 210, 861-874. [CrossRef] [PubMed]

39. Mommer, L.; Visser, E.J.W.; Ruijven, J.; Caluwe, H.; Pierik, R.; Kroon, H. Contrasting root behavior in two grass species: A test of functionality in dynamic heterogeneous conditions. Plant Soil 2011, 344, 347-360. [CrossRef]

40. Hüppi, R.; Neftel, A.; Lehmann, M.F.; Krauss, M.; Six, J.; Leifeld, J. N use efficiencies and $\mathrm{N}_{2} \mathrm{O}$ emissions in two contrasting, biochar amended soils under winter wheat-cover crop-sorghum rotation. Environ. Res. Lett. 2016, 11, 084013. [CrossRef]

41. Schwenke, G.D.; Haigh, B.M. The interaction of seasonal rainfall and nitrogen fertiliser rate on soil $\mathrm{N}_{2} \mathrm{O}$ emission, total $\mathrm{N}$ loss and crop yield of dryland sorghum and sunflower grown on sub-tropical vertosols. Soil Res. 2016, 54, 604-618. [CrossRef]

42. Liu, X.; Shen, Y. Quantification of the impacts of climate change and human agricultural activities on oasis water requirements in an arid region: A case study of the Heihe river basin, China. Earth Syst. Dyn. 2018, 9 , 211-225. [CrossRef]

43. Rubio, G.; Boem, F.H.G.; Lavado, R.S. Responses of C3 and C4 grasses to application of nitrogen and phosphorus fertilizer at two dates in the spring. Grass Forage Sci. 2010, 65, 102-109. [CrossRef]

44. Wang, H.; Beule, L.; Zang, H.; Pfeiffer, B.; Dittert, K. Growing grass reduces soil $\mathrm{N}_{2} \mathrm{O}$ emissions and stimulates proliferation of denitrifying bacteria. Sci. Total Environ. 2020, 18, 136778. [CrossRef]

45. Trost, B.; Prochnow, A.; Drastig, K.; Meyer-Aurich, A.; Ellmer, F.; Baumecker, M. Irrigation, soil organic carbon and $\mathrm{N}_{2} \mathrm{O}$ emissions. Rev. Agron. Sustain. Dev. 2013, 33, 733-749. [CrossRef]

46. Pang, J.; Wang, X.; Mu, Y.; Ouyang, Z.; Zhang, H. Nitrous oxide emissions from winter wheat field in the loess plateau. Acta Ecol. Sin. 2011, 31, 1896-1903.

47. Schindlbacher, A.; Zechmeister-Boltenstern, S.; Butterbach-Bahl, K. Effects of soil moisture and temperature on $\mathrm{NO}, \mathrm{NO}_{2}$, and $\mathrm{N}_{2} \mathrm{O}$ emissions from European forest soils. J. Geophys. Res. Atmos. 2004, 109, 17302. [CrossRef]

48. Schaufler, G.; Kitzler, B.; Schindlbacher, A.; Skiba, U.; Sutton, M.A.; Zechmeister-Boltenstern, S. Greenhouse gas emissions from European soils under different land use: Effects of soil moisture and temperature. Eur. J. Soil Sci. 2010, 61, 683-696. [CrossRef]

49. Kim, D.G.; Vargas, R.; Bond-Lamberty, B.; Turetsky, M.R. Effects of soil rewetting and thawing on soil gas fluxes: A review of current literature and suggestions for future research. Biogeosciences 2012, 9, 2459-2483. [CrossRef]

50. Pittelkow, C.; Adviento-Borbe, M.A.; Van Kessel, C.; Hill, J.E.; Linquist, B.A. Optimizing rice yields while minimizing yield-scaled global warming potential. Glob. Chang. Biol. 2014, 20, 1382-1393. [CrossRef]

(C) 2020 by the authors. Licensee MDPI, Basel, Switzerland. This article is an open access article distributed under the terms and conditions of the Creative Commons Attribution (CC BY) license (http://creativecommons.org/licenses/by/4.0/). 